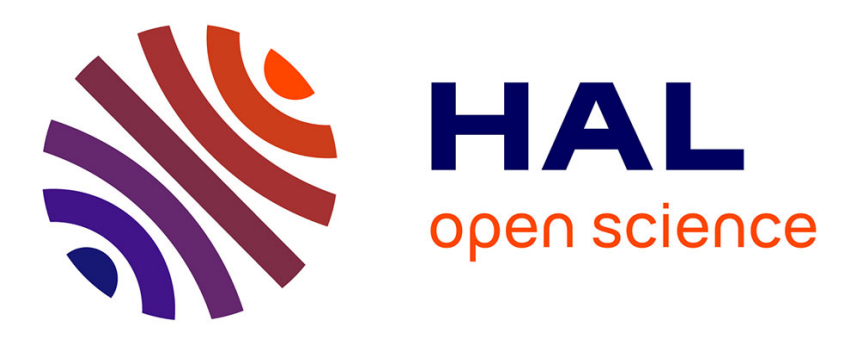

\title{
Circulating CD34+KDR + endothelial progenitor cells are reduced in chronic heart failure patients as a function of Type D personality
}

Emeline M. van Craenenbroeck, Johan Denollet, Bernard P. Paelinck, Paul Beckers, Nadine Possemiers, Vicky Y. Hoymans, Christiaan J. Vrints, Viviane M. Conraads

\section{To cite this version:}

Emeline M. van Craenenbroeck, Johan Denollet, Bernard P. Paelinck, Paul Beckers, Nadine Possemiers, et al.. Circulating CD34+KDR+ endothelial progenitor cells are reduced in chronic heart failure patients as a function of Type D personality. Clinical Science, 2009, 117 (4), pp.165-172. 10.1042/CS20080564 . hal-00502880

\section{HAL Id: hal-00502880 \\ https://hal.science/hal-00502880}

Submitted on 16 Jul 2010

HAL is a multi-disciplinary open access archive for the deposit and dissemination of scientific research documents, whether they are published or not. The documents may come from teaching and research institutions in France or abroad, or from public or private research centers.
L'archive ouverte pluridisciplinaire HAL, est destinée au dépôt et à la diffusion de documents scientifiques de niveau recherche, publiés ou non, émanant des établissements d'enseignement et de recherche français ou étrangers, des laboratoires publics ou privés. 


\title{
Circulating CD34+KDR+ Endothelial Progenitor Cells are Reduced in Chronic Heart Failure Patients as a Function of Type D Personality.
}

\author{
Emeline M. Van Craenenbroeck ${ }^{1,2,3}$, Johan Denollet ${ }^{1,4}$, Bernard P. Paelinck ${ }^{1}$, Paul \\ Beckers $^{1}$, Nadine Possemiers ${ }^{1}$, Vicky Y. Hoymans ${ }^{2,3}$, Christiaan J. Vrints ${ }^{1,2,3}$, \\ Viviane M. Conraads ${ }^{1,2,3}$
}

${ }^{1}$ Department of Cardiology, Antwerp University Hospital, Wilrijkstraat 10, 2650

Edegem, Belgium

${ }^{2}$ Laboratory of Molecular and Cellular Cardiology, Antwerp University Hospital, Wilrijkstraat 10, 2650 Edegem, Belgium

${ }^{3}$ Center for Cell Therapy and Regenerative Medicine (CCRG), Antwerp University Hospital, Wilrijkstraat 10, 2650 Edegem, Belgium

${ }^{4}$ Center of Research on Psychology in Somatic diseases (CoRPS), Tilburg University, PO Box 90153, 5000 LE Tilburg, The Netherlands

Keywords: Endothelium- Endothelial progenitor cells- Type D Personality- Heart Failure

Short Title: Reduced Endothelial Progenitors in Type D personality

\section{Correspondence to:}

Emeline Van Craenenbroeck

Department of Cardiology

Antwerp University Hospital

Wilrijkstraat 10, 2650 Edegem

Belgium

Tel ++3238214098

Fax ++3238302305

Email: emeline.vancraenenbroeck@ua.ac.be 


\section{ABSTRACT}

Aims: The aim of this study was to assess whether EPC number/function might be an explanatory factor for the observed relation between Type D personality (a joint tendency toward negative affectivity and social inhibition) and poor cardiovascular prognosis. We also assessed whether the effect of a single exercise bout on EPC number/function is affected by Type D personality.

Methods and results: Thirty-five sedentary men with chronic heart failure ( $\mathrm{CHF}$; left ventricular ejection fraction $\leq 45 \%$ ) underwent cardio-pulmonary exercise testing (CPET) and personality assessment with the 14-item Type D Scale. CD34+/KDR+ cells were quantified by flow cytometry before and immediately after CPET. Migration of early EPC towards vascular endothelial growth factor and stromal cellderived factor- $1 \alpha$ was investigated. Type $D(n=10)$ and non-Type $D$ patients $(n=25)$ were comparable with regards to demographics, disease severity and Framingham risk factor score. Circulating EPC numbers were reduced by $54 \%$ in Type D versus nonType D patients $(0.084 \pm 0.055$ vs. $0.183 \pm 0.029, \%$ of lymphocytes, $P=0.006)$. Exercise led to a $60 \%$ increase in EPC in Type D patients whereas the EPC number remained unchanged in the non-Type $\mathrm{D}$ group $(P=0.049)$. Baseline migratory capacity was related to disease severity but was not different comparing Type D and non-Type D patients. Exercise induced a highly significant enhancement of migratory capacity in both groups.

Conclusions: Reduced EPC numbers might explain impaired cardiovascular outcome in Type D patients. The observed larger increase in circulating EPC in these patients suggests that acute exercise elicits a more pronounced stimulus for endothelial repair. 


\section{INTRODUCTION}

Type D personality - a joint tendency toward negative affectivity (NA) and social inhibition (SI) - is associated with poor prognosis in cardiovascular patients [1]. The relation between emotional distress and cardiovascular disease has been linked to an unhealthy lifestyle, but also to more physiological processes such as disturbed autonomic control [2], impaired platelet function [3] and a pro-inflammatory environment [4]. Recently, decreased numbers of endothelial progenitor cells (EPC) have been put forward as another possible mediator of cardiovascular disorders in depressed patients [5]. In line with this, psychosocial risk factors are related to levels of circulating progenitor cells, independent of classical cardiovascular risk factors [6]. Accumulating evidence suggests that the quantity and function of circulating EPC play an important role in preserving endothelial integrity. These cells are released from the bone marrow in response to ischemia or endothelial injury and aim to repair damaged regions, either by producing angiogenic cytokines [7] or by differentiating into endothelial cells [8]. Besides re-endothelialization, EPC play a role in postischemic neoangiogenisis [9]. The therapeutic use of EPC and bone marrow mononuclear cells after vascular injury seems promising $[10,11]$, but safety issues need to be further addressed [12].

In patients at cardiovascular risk [13], in those with coronary artery disease (CAD) [14] and in chronic heart failure (CHF) patients [15], the number of circulating EPC is reduced. In addition to this quantitative deficit, subnormal function of EPC correlates with impaired endothelial function [16]. Diversity in terms of EPC definition and quantification methods has complicated cross study comparisons [17], sometimes leading to paradoxical findings, such as increased numbers of EPC in patients with higher cardiovascular risk [18].

Psychological distress promotes immune dysregulation [19], which in turn might mediate bone-marrow suppression or cause depletion of EPC in the peripheral circulation. We previously demonstrated that Type D personality in CHF patients is independently associated with increased circulating levels of TNF- $\alpha$ and its soluble receptors [20] that have been shown to predict poor outcome in CHF [21,22].

Physical training has proved to be of clear benefit in cardiovascular patients. Besides the central haemodynamic effect, exercise tolerance is improved by partially restoring vascular reactivity. Shear stress induced up-regulation of endothelial nitric oxide synthase (eNOS) and reduction of oxidative stress play a central regulatory function. Moreover, recent studies demonstrate that regular physical exercise mobilizes EPC in CAD and CHF patients [23] which might explain the observed benefit on endothelial function.

An acute exercise bout in sedentary patients, however, poses a threat to endothelial integrity by inducing vascular oxidative stress and a transient prothrombotic stimulus. In the present study, we investigated the relation between Type D personality and EPC numbers and their function in CHF patients before and after endothelial stress elicited by a symptom-limited cardio-pulmonary exercise test (CPET). 


\section{METHODS}

\section{Patients}

Thirty-five consecutive sedentary male CHF patients with left ventricular ejection fraction $(\mathrm{LVEF}) \leq 45 \%$, followed at the outpatient heart failure clinic of the Department of Cardiology were recruited for this study. They were stable with regard to symptoms and therapy for at least one month, and were on standard medical treatment consisting of ACE-inhibitors or angiotensin receptor blockers, betablockers, diuretics and spironolactone as indicated. Patients with active infection or cancer and patients on anti-inflammatory drugs were excluded. The study complies with the Declaration of Helsinki, was approved by the local ethics committee and written informed consent was obtained from all patients.

\section{Study design}

Complete clinical assessment, including resting blood-pressure measurement and New York Heart Association (NYHA) classification, was performed at the time of enrollment. The total burden of cardiovascular risk factors was calculated with use of the Framingham risk factor score [24]. Left ventricular ejection fraction was determined using echocardiography (Simpson's rule). Fasting blood samples were collected in order to measure complete blood cell count, creatinine, glucose and lipid levels. Subjects performed a symptom-limited CPET on a graded bicycle ergometer. Immediately before and 10 minutes after peak exercise, venous blood samples were drawn from an antecubital vein and collected in acid citrate dextrose (ACD) tubes. Samples were processed immediately or stored at $4^{\circ} \mathrm{C}$ and analyzed within 4 hours.

\section{Clinical data and Type $D$ personality}

All 35 patients completed the 14-item Type D Scale (DS14). The DS14 comprises a 7-item subscale measuring negative affectivity and a 7-item subscale measuring social inhibition. A cut-off of $\geq 10$ on both DS14 subscales was used to classify patients as Type D personality [25].

\section{Cardiopulmonary exercise test (CPET)}

To obtain an optimal duration of the CPET between 8 and 10 minutes, 2 ramp protocols were used; patients started either with 20 or 40 Watts, with and incremental load of 10 versus 20 Watts every minute, respectively. Twelve-lead ECG and heart rate were recorded continuously whereas automatic cuff blood pressure was measured every 2 minutes and at peak exercise. Breath-by-breath gas exchange measurements allowed on-line determination of ventilation (VE), oxygen uptake $\left(\mathrm{VO}_{2}\right)$ and carbon dioxide production $\left(\mathrm{VCO}_{2}\right)$ every 15 seconds. Peak oxygen consumption $\left(\mathrm{VO}_{2}\right.$ peak $)$ was determined as the highest attained $\mathrm{VO}_{2}$ during the final 30 seconds of exercise and was also expressed as a percentage of the predicted value $\left(\mathrm{VO}_{2}\right.$ peak\%). Online analysis of $\mathrm{VE} / \mathrm{VO}_{2}$ and $\mathrm{VE} / \mathrm{VCO}_{2}$ curves permitted to encourage patients to exercise up to exhaustion.

\section{Assessment of endothelium-dependent vasodilation and intima-media thickness}

Endothelium-dependent vasodilation was assessed in supine position by ultrasound of the right brachial artery (AU5 ultrasound system, Esaote, Biomedica, Genova, Italy). End-diastolic diameters were evaluated at rest and during reactive hyperaemia after inflating and deflating a forearm blood pressure cuff $(200 \mathrm{mmHg}$ or at least $50 \mathrm{mmHg}$ above peak systolic pressure for $4 \mathrm{~min}$ ). Post-occlusion measurements were taken every $30 \mathrm{~s}$ and over the following 240s. Endothelium-dependent dilation was 
determined as the percentage change in diameter between baseline and maximal postocclusion values.

Intima media thickness (IMT) was measured with high-resolution ultrasound at the posterior wall of the common carotid artery using an automated edge-tracking method.

\section{Quantification of circulating CD34+/KDR + cells}

CD34+/KDR+ cells, commonly used membrane markers to define EPC, were detected by flow cytometry. In brief, $200 \mu 1$ peripheral whole blood was pre-treated with FcR blocking reagent (Miltenyi) to prevent non-specific binding and incubated with anti-KDR-PE (R\&D) and anti-CD34-PeCy7 (BD) antibodies. After red blood cell lysis with ammoniumchloride (Stem Cell Technologies), a total of $10^{6}$ events was recorded on a FACSCantoII flow cytometer (BD). Time was entered as a parameter to facilitate the identification and removal of events bursts and minor clogs. Before analysis, the flow cytometer was thoroughly cleaned to remove residual cells. Fluorochrome and isotype matched controls as well as unstained cell samples were measured and processed as negative controls to set the appropriate regions. The numbers of $\mathrm{CD} 34+/ \mathrm{KDR}+$ cells were analyzed in the lymphocyte region using FACSDiVa software and expressed as percentage of lymphocytes.

\section{Migratory activity of early EPC}

Peripheral blood mononuclear cells (PBMC) were isolated by density gradient centrifugation with Lymphosep (MP Biomedicals) and cultured on fibronectin coated 24-well dishes in EGM-2 MV, supplemented with 20\% fetal calf serum. On day 7, cells were characterized as early EPC by uptake of acetylated LDL (DiI-acLDL, Molecular probes) and binding of FITC-conjugated lectin from Ulex europeus (UEA1, Sigma). Migratory activity of EPC towards vascular endothelial growth factor (VEGF, $50 \mathrm{ng} / \mathrm{ml}, \mathrm{R} \& \mathrm{D}$ systems) and stromal cell-derived factor-1 $\alpha$ (SDF-1 $\alpha, 100$ $\mathrm{ng} / \mathrm{ml}, \mathrm{R} \& \mathrm{D}$ systems) was investigated using $5 \mu \mathrm{m}$ transwells (Corning Costar). After 4 hours, viable EPC that had migrated to the lower chamber were stained with trypan blue and counted manually using a hemacytometer. EPC counted in the negative control transwell (no addition of chemo-attractants) were subtracted from this number. Migrated EPC were expressed as percentage of total cell number added tot the transwell (positive contro1).

\section{Statistical analysis}

Continuous data are expressed as means \pm standard error of mean. Normality of data was assessed using a one-sample Kolmogorov Smirnov. Independent samples $t$ - and $\chi^{2}-$ test were used as appropriate for baseline measurements. Pre -and post exercise data were compared in the 2 groups using paired sampled $t$ - tests with Levene's test for equality of variances. Calculating the difference in mean EPC levels between Type D and non-Type D patients, and dividing it by the standard deviation of the total group at baseline estimated an effect size of Type D personality. An effect size of 0.50 reflects a moderate effect and 0.80 a large effect [27]. In order to estimate the magnitude of the Type D effect on EPC numbers, we compared its effect size with those of older age and standard cardiovascular risk factors. A median split was used to dichotomize EPC levels in order to stratify patients in high-and low-risk groups, respectively. Multiple logistic regression (method=enter) was used to determine the risk associated with Type $\mathrm{D}$ personality after controlling for age, body mass index (BMI) and LVEF). 
All analyses were performed using SPSS 16.0 for Windows. A two-tailed P-value of $<0.05$ was considered statistically significant. 


\section{RESULTS}

Patient characteristics according to Type D classification

According to the DS14 Type D Scale, 10 out of the 35 CHF patients enrolled were classified as Type D. Demographic characteristics, NYHA classification, LVEF, FMD, IMT, disease etiology, cardiovascular risk factors and medication were comparable in Type D and non-Type D patients (Table 1). None of the patients received other medications with known effects on EPC number and function (i.e.: PPAR- $\gamma$ agonists, calcium antagonists, organic nitrates, PDE-5 inhibitors).

Baseline number of circulating CD34+/KDR + cells (EPC) and function of early EPC As presented in Figure 1, circulating EPC numbers were significantly reduced by $54 \%$ in Type D patients $(0.084 \pm 0.055 \%$ of lymphocytes $)$ compared to non-Type D patients $(0.183 \pm 0.029, \%$ of lymphocytes, $P=0.006)$.

Figure 2 illustrates the importance of Type D personality as a determinant of EPC number in the present study. The effect size of 0.8 indicates that Type D personality had a large effect on EPC numbers. In comparison, advanced age (effect size $=0.46$ ) and unfavorable standard cardiovascular risk profile (effect size $=0.17$ ) had a small effect. Hence, the effect of Type D personality was larger than that of these wellknown determinants of EPC numbers. Apart from Type D personality, age, BMI and LVEF were included in a multiple logistic regression model in order to control for factors known to influence EPC numbers [15,28,29]. This model retained Type D personality as an independent predictor of low EPC levels (Odds ratio 8.2; 95 \% CI 1.2-57.4, $P=0.034$ ).

The number of circulating EPC was not related to determinants of disease severity such as poor LVEF and reduced $\mathrm{VO}_{2}$ peak (all $P>0.05$ ).

Migratory capacity correlated with the percentage of the predicted $\mathrm{VO}_{2}$ peak $(\mathrm{r}=$ $0.334, P=0.053)$ and inversely with NT-proBNP levels $(\mathrm{r}=-0.409, P=0.031)$. However, migratory activity of early EPC was not different in Type D versus nonType D patients $(34.9 \pm 3.4$ versus $37.1 \pm 5.4 \%, P=0.73)$.

\section{Effect of exercise on EPC number and function}

Changes in numbers of circulating EPC and migratory activity of early EPC following CPET are shown in Figure 3. A single exercise bout led to a $60 \%$ increase in EPC in Type D patients whereas the EPC number remained unchanged in the non-Type D group $(P=0.049)$. Migratory capacity of early EPC improved significantly after exercise in both Type D and non-Type D patients (Figure 3B). This increase was comparable in the 2 groups $(P=0.97)$. 


\section{DISCUSSION}

Depletion and altered function of EPC have been demonstrated in CHF, which is characterized by endothelial dysfunction. In cardiac patients, advanced age and unfavorable cardiovascular risk profile [14] are well-known determinants of reduced circulating EPC numbers. The present findings are the first to suggest that Type D personality may also be associated with significantly impaired release and or/survival of circulating EPC in CHF patients.

The potential importance of Type D personality was demonstrated by its large effect size, as compared to that of standard clinical factors affecting EPC numbers. Individuals with a Type D personality tend to experience the ongoing situations in their life as stressful, which, in turn, may elicit negative emotional reactions and physiological hyperreactivity every time a potentially "threatening" situation is encountered [30]. Previous work demonstrated that Type D personality is independently associated with increased concentrations of the pro-inflammatory cytokine TNF- $\alpha$ and its soluble receptors [20], increased levels of the stress hormone cortisol [31] and a disrupted autonomic balance [32]. These physiological stress mechanisms may help to clarify the link between Type D personality and reduced EPC numbers in the present study.

Dome et al. [5] recently showed a disbalance of pro-and anti-inflammatory cytokines in patients with depression, which was associated with reduced EPC numbers. In a study of Valgimigli et al. [15], lower numbers of circulating EPC in severe CHF were linked to increased serum concentrations of TNF- $\alpha$. In vitro experiments have demonstrated that TNF- $\alpha$ causes growth suppression of bone marrow CD34+ hematopoietic stem cells [33] and induces apoptosis of peripheral circulating EPC [34]. In line with this, it is conceivable that the increased TNF- $\alpha$ activity observed in Type D personality [35] induces suppression of bone marrow hematopoietic stem cells, thereby limiting the number of circulating progenitor cells.

Activation of the hypothalamic-pituitary-adrenal (HPA) axis in Type D personality and a subsequent increased production of cortisol and catecholamines [32,36] could provide a second plausible mechanism. Both endogenously produced, as well as synthetic steroids induce substantial losses of lymphoid precursor cells in the bone marrow via apoptotic pathways [37,38]. Moreover, hydrocortisone hampers the differentiation of human CD34+ cells towards lymphocytes in in vitro experiments [39].

Thirdly, it is conceivable that the disrupted autonomic balance in Type D personality [2] partially accounts for the lower EPC counts. The bone marrow is supplied by autonomic, sympathetic efferent innervation [40], which plays a role in the proliferation and release of hematopoietic cells from the bone marrow [41].

The maintenance of an intact endothelial monolayer, either by adjacent mature endothelial celis or by EPC, prevents the development of atherosclerosis. Endothelial progenitor cells also affect disease progression and determine prognosis independently of known cardiovascular risk factors [14]. To a large extent, endothelial-dependent vasodilation determines functional capacity of patients. Measures taken to ameliorate endothelial vasoreactivity, such as physical training, partially restore endothelial dysfunction [22], and EPC have been put forward as key regulators. An acute exercise bout, however, poses a threat to endothelial integrity by inducing vascular oxidative stress and a transient prothrombotic stimulus. It has been shown in healthy subjects, that circulating EPC numbers increase following a maximal exercise bout [42], thereby supporting the conjecture that the generation of 
reactive oxygen species may trigger EPC release. The present findings demonstrate that the exercise-induced stimulus for endothelial restoration is larger in Type D patients than in non-Type D patients. The more pronounced release of EPC might be considered a mechanism of defence in order to compensate for the observed chronic deficit in circulating EPC numbers at rest.

While the number of circulating EPC was lower in Type D patients, their migratory capacity was not. However, recent evidence suggests that CD34+/DKR+ cells and socalled "early EPC", cultivated in vitro, are in fact different endothelial progenitor cell subpopulations, characterized by other antigenic cell surface markers and different angiogenic properties [43].

The present data should be interpreted with caution since the number of patients investigated is limited. Nevertheless, the effect size for Type D personality was remarkably high, in comparison to known determinants of circulating EPC numbers. The absence of a relation between EPC numbers and disease severity in this small group of patients might be explained by the fact that the group is rather homogenous. In addition, the main purpose of the study was to try to identify disease-modifying mechanisms that might help to explain why Type D patients are prone to repeated cardiovascular events and poor prognosis.

Several studies have shown that Type D personality predicts poor prognosis in cardiac patients. The exact biological pathways by which Type D personality predisposes to cardiovascular disease still awaits further clarification. The findings of the present study are the first to suggest that Type D personality may contribute to the pathophysiology of cardiovascular disease by mediating the number of circulating EPC. Future studies should be designed to investigate possible underlying mechanisms, using both in vivo en and in vitro experiments. 


\section{ACKNOWLEDGEMENTS}

The authors have no conflict of interest to declare. 


\section{FUNDING}

This research was supported by a grant from the Fund for Scientific Research, Flanders, Belgium (FWO-Vlaanderen) to Drs. Emeline Van Craenenbroeck and Viviane Conraads, and by VICI grant (\#453-04-004) from the Netherlands Organization for Scientific Research (The Netherlands) to Dr. Johan Denollet. 


\section{REFERENCES}

1 Denollet, J., Sys, S.U., Stroobant, N., Rombouts, H., Gillebert, T.C., and Brutsaert, D.L. (1996) Personality as independent predictor of long-term mortality in patients with coronary heart disease. Lancet 347, 417-421

2 Carney, R.M., Blumenthal, J.A., Stein, P.K., Watkins, L., Catellier, D., Berkman, L.F., Czajkowski, S.M., O'Connor, C., Stone, P.H., and Freedland, K.E. (2001) Depression, heart rate variability, and acute myocardial infarction. Circulation 104, 2024-2028

3 Musselman, D.L., Tomer, A., Manatunga, A.K., Knight, B.T., Porter, M.R., Kasey, S., Marzec, U., Harker, L.A., and Nemeroff, C.B. (1996) Exaggerated platelet reactivity in major depression. Am. J. Psychiatry 153, 1313-1317

4 Appels, A., Bar, F.W., Bar, J., Bruggeman, C., and de Baets, M. (2000) Inflammation, depressive symptomtology, and coronary artery disease. Psychosom. Med. 62, 601-605

5 Dome, P., Teleki, Z., Rihmer, Z., Peter, L., Dobos, J., Kenessey, I., Tovari, J., Timar, J., Paku, S., Kovacs, G., and Dome, B. (2008) Circulating endothelial progenitor cells and depression: a possible novel link between heart and soul. Mol. Psychiatry, doi: 10.1038/sj.mp.4002138

6 Fischer, J.C., Kudielka, B.M., von Kanel, R., Siegrist, J., Thayer, J.F., and Fischer, J.E. (2008) Bone-marrow derived progenitor cells are associated with psychosocial determinants of health after controlling for classical biological and behavioral cardiovascular risk factors. Brain Behav. Immun. doi: 10.1016/j.bbi.2008.08.005

Hur, J., Yoon, C.H., Kim, H.S., Choi, J.H., Kang, H.J., Hwang, K.K., Oh, B.H., Lee, M.M., and Park, Y.B. (2004) Characterization of two types of endothelial progenitor cells and their different contributions to neovasculogenesis. Arterioscler. Thromb. Vasc. Biol. 24, 288-293

8 Wassmann, S., Werner, N., Czech, T., and Nickenig, G. (2006) Improvement of endothelial function by systemic transfusion of vascular progenitor cells. Circ. Res. 99, e74-83

9 Rafii, S., and Lyden, D. (2003) Therapeutic stem and progenitor cell transplantation for organ vascularization and regeneration. Nat. Med. 9, 702712

10 Schachinger, V., Assmus, B., Britten, M.B., Honold, J., Lehmann, R., Teupe, C., Abolmaali, N.D., Vogl, T.J., Hofmann, W.K., Martin, H., Dimmeler, S., and Zeiher, A.M. (2004) Transplantation of progenitor cells and regeneration enhancement in acute myocardial infarction: final one-year results of the TOPCARE-AMI Trial. J. Am. Coll. Cardiol. 44, 1690-1699

11 Janssens, S., Dubois, C., Bogaert, J., Theunissen, K., Deroose, C., Desmet, W., Kalantzi, M., Herbots, L., Sinnaeve, P., Dens, J., Maertens, J., Rademakers, F., Dymarkowski, S., Gheysens, O., Van Cleemput, J., Bormans, G., Nuyts, J., Belmans, A., Mortelmans, L., Boogaerts, M., and Van de Werf, F. (2006) Autologous bone marrow-derived stem-cell transfer in patients with ST-segment elevation myocardial infarction: double-blind, randomised controlled trial. Lancet 367, 113-121

12 Silvestre, J.S., Gojova, A., Brun, V., Potteaux, S., Esposito, B., Duriez, M., Clergue, M., Le Ricousse-Roussanne, S., Barateau, V., Merval, R., Groux, H., Tobelem, G., Levy, B., Tedgui, A., and Mallat, Z. (2003) Transplantation of bone marrow-derived mononuclear cells in ischemic apolipoprotein E- 
knockout mice accelerates atherosclerosis without altering plaque composition. Circulation 108, 2839-2842

13 Werner, N., Kosiol, S., Schiegl, T., Ahlers, P., Walenta, K., Link, A., Bohm, M., and Nickenig, G. (2005) Circulating endothelial progenitor cells and cardiovascular outcomes. N. Engl. J. Med. 353, 999-1007

14 Schmidt-Lucke, C., Rossig, L., Fichtlscherer, S., Vasa, M., Britten, M., Kamper, U., Dimmeler, S., and Zeiher, A.M. (2005) Reduced number of circulating endothelial progenitor cells predicts future cardiovascular events: proof of concept for the clinical importance of endogenous vascular repair. Circulation 111, 2981-2987

15 Valgimigli, M., Rigolin, G.M., Fucili, A., Porta, M.D., Soukhomovskaia, O., Malagutti, P., Bugli, A.M., Bragotti, L.Z., Francolini, G., Mauro, E., Castoldi, G., and Ferrari, R. (2004) CD34+ and endothelial progenitor cells in patients with various degrees of congestive heart failure. Circulation 110, 1209-1212

16 Heiss, C., Keymel, S., Niesler, U., Ziemann, J., Kelm, M., and Kalka, C. (2005) Impaired progenitor cell activity in age-related endothelial dysfunction. J. Am. Coll. Cardiol. 45, 1441-1448

17 Fadini, G.P., Baesso, I., Albiero, M., Sartore, S., Agostini, C., and Avogaro, A. (2008) Technical notes on endothelial progenitor cells: ways to escape from the knowledge plateau. Atherosclerosis 197, 496-503

18 Xiao, Q., Kiechl, S., Patel, S., Oberhollenzer, F., Weger, S., Mayr, A., Metzler, B., Reindl, M., Hu, Y., Willeit, J., and Xu, Q. (2007) Endothelial progenitor cells, cardiovascular risk factors, cytokine levels and atherosclerosis--results from a large population-based study. PLoS ONE 2, e975

19 Gidron, Y., Gilutz, H., Berger, R., and Huleihel, M. (2002) Molecular and cellular interface between behavior and acute coronary syndromes. Cardiovasc. Res. 56, 15-21

20 Conraads, V.M., Denollet, J., De Clerck, L.S., Stevens, W.J., Bridts, C., and Vrints, C.J. (2006) Type D personality is associated with increased levels of tumour necrosis factor (TNF)-alpha and TNF-alpha receptors in chronic heart failure. Int. J. Cardiol. 113, 34-38

21 Rauchhaus, M., Doehner, W., Francis, D.P., Davos, C., Kemp, M., Liebenthal, C., Niebauer, J., Hooper, J., Volk, H.D., Coats, A.J., and Anker, S.D. (2000) Plasma cytokine parameters and mortality in patients with chronic heart failure. Circulation 102, 3060-3067

22 Hambrecht, R., Fiehn, E., Weigl, C., Gielen, S., Hamann, C., Kaiser, R., Yu, J., Adams, V., Niebauer, J., and Schuler, G. (1998) Regular physical exercise corrects endothelial dysfunction and improves exercise capacity in patients with chronic heart failure. Circulation 98, 2709-2715

23 Sarto, P., Balducci, E., Balconi, G., Fiordaliso, F., Merlo, L., Tuzzato, G., Pappagallo, G.L., Frigato, N., Zanocco, A., Forestieri, C., Azzarello, G., Mazzucco, A., Valenti, M.T., Alborino, F., Noventa, D., Vinante, O., Pascotto, P., Sartore, S., Dejana, E., and Latini, R. (2007) Effects of exercise training on endothelial progenitor cells in patients with chronic heart failure. J. Card. Fail. 13, 701-708

24 Hill, J.M., Zalos, G., Halcox, J.P., Schenke, W.H., Waclawiw, M.A., Quyyumi, A.A., and Finkel, T. (2003) Circulating endothelial progenitor cells, vascular function, and cardiovascular risk. N. Engl. J. Med. 348, 593-600 
25 Denollet, J. (2005) DS14: standard assessment of negative affectivity, social inhibition, and Type D personality. Psychosom. Med. 67, 89-97

27 Cohen, J. (1988) Statistical Power Analysis for the Behavioral Sciences, $2^{\text {nd }}$ end, Lawrence Erlbaum Associates

28 Scheubel, R.J., Zorn, H., Silber, R.E., Kuss, O., Morawietz, H., Holtz, J., and Simm, A. (2003) Age-dependent depression in circulating endothelial progenitor cells in patients undergoing coronary artery bypass grafting. J. Am. Coll. Cardiol. 42, 2073-2080

29 Westerweel, P.E., Visseren, F.L., Hajer, G.R., Olijhoek, J.K., Hoefer, I.E., de Bree, P., Rafii, S., Doevendans, P.A., and Verhaar, M.C. (2008) Endothelial progenitor cell levels in obese men with the metabolic syndrome and the effect of simvastatin monotherapy vs. simvastatin/ezetimibe combination therapy. Eur. Heart J. 29, 2808-2817

30 Habra, M.E., Linden, W., Anderson, J.C., and Weinberg, J. (2003) Type D personality is related to cardiovascular and neuroendocrine reactivity to acute stress. J. Psychosom. Res. 55, 235-245

31 Whitehead, D.L., Perkins-Porras, L., Strike, P.C., Magid, K., and Steptoe, A. (2007) Cortisol awakening response is elevated in acute coronary syndrome patients with type-D personality. J. Psychosom. Res. 62, 419-425

32 Sher, L. (2005) Type D personality: the heart, stress, and cortisol. Q. J. Med. 98, 323-329

33 Hu, X., Tang, M., Fisher, A.B., Olashaw, N., and Zuckerman, K.S. (1999) TNF-alpha-induced growth suppression of CD34+ myeloid leukemic cell lines signals through TNF receptor type $\mathrm{I}$ and is associated with NF-kappa B activation. J. Immunol. 163, 3106-3115

34 Henrich, D., Seebach, C., Wilhelm, K., and Marzi, I. (2007) High dosage of simvastatin reduces TNF-alpha-induced apoptosis of endothelial progenitor cells but fails to prevent apoptosis induced by IL-1beta in vitro. J. Surg. Res. 142, 13-19

35 Denollet, J., Vrints, C.J., and Conraads, V.M. (2008) Comparing Type D personality and older age as correlates of tumor necrosis factor-alpha dysregulation in chronic heart failure. Brain Behav. Immun. 22, 736-743

36 Molloy, G.J., Perkins-Porras, L., Strike, P.C., and Steptoe, A. (2008) Type-D personality and cortisol in survivors of acute coronary syndrome. Psychosom. Med. 70, 863-868

37 Garvy, B.A., King, L.E., Telford, W.G., Morford, L.A., and Fraker, P.J. (1993) Chronic elevation of plasma corticosterone causes reductions in the number of cycling cells of the B lineage in murine bone marrow and induces apoptosis. Immunology 80, 587-592

38 Lill-Elghanian, D., Schwartz, K., King, L., and Fraker, P. (2002) Glucocorticoid-induced apoptosis in early B cells from human bone marrow. Exp. Biol. Med. (Maywood) 227, 763-770

39 Igarashi, H., Medina, K.L., Yokota, T., Rossi, M.I., Sakaguchi, N., Comp, P.C., and Kincade, P.W. (2005) Early lymphoid progenitors in mouse and man are highly sensitive to glucocorticoids. Int. Immunol. 17, 501-511

40 Artico, M., Bosco, S., Cavallotti, C., Agostinelli, E., Giuliani-Piccari, G., Sciorio, S., Cocco, L., and Vitale, M. (2002) Noradrenergic and cholinergic innervation of the bone marrow. Int. J. Mol. Med. 10, 77-80

41 Spiegel, A., Shivtiel, S., Kalinkovich, A., Ludin, A., Netzer, N., Goichberg, P., Azaria, Y., Resnick, I., Hardan, I., Ben-Hur, H., Nagler, A., Rubinstein, M., 
and Lapidot, T. (2007) Catecholaminergic neurotransmitters regulate migration and repopulation of immature human CD34+ cells through Wnt signaling. Nat. Immunol. 8, 1123-1131

42 Van Craenenbroeck, E.M., Vrints, C.J., Haine, S.E., Vermeulen, K., Goovaerts, I., Van Tendeloo, V.F., Hoymans, V.Y., and Conraads, V.M. (2008) A maximal exercise bout increases the number of circulating $\mathrm{CD} 34+/ \mathrm{KDR}+$ endothelial progenitor cells in healthy subjects. Relation with lipid profile. J. Appl. Physiol. 104, 1006-1013

43 Sieveking, D.P., Buckle, A., Celermajer, D.S., and Ng, M.K. (2008) Strikingly different angiogenic properties of endothelial progenitor cell subpopulations: insights from a novel human angiogenesis assay. J. Am. Coll. Cardiol. 51, 660-668 


\section{TABLES}

TABLE 1. Demographic and clinical characteristics as a function of Type D personality

\begin{tabular}{|c|c|c|c|}
\hline & Non-Type D $(\mathbf{n}=\mathbf{2 5})$ & Type D $(n=10)$ & $P$-value \\
\hline Age (yrs) & $63.4 \pm 2.6$ & $56.3 \pm 3.0$ & 0.1 \\
\hline BMI & $27.0 \pm 0.7$ & $25.5 \pm 1.6$ & 0.4 \\
\hline Framingham Risk Factor Score & $4.5 \pm 0.6$ & $5.2 \pm 1.0$ & 0.5 \\
\hline Diabetes mellitus (\%) & $2(8 \%)$ & $1(10 \%)$ & 0.7 \\
\hline Creatinine clearance rate $(\mathrm{ml} / \mathrm{min})$ & $62.7 \pm 6.7$ & $69.4 \pm 6.4$ & 0.6 \\
\hline NYHA class I-II-III & $5-11-9$ & $0-8-2$ & 0.1 \\
\hline Ischemic etiology (\%) & $19(76 \%)$ & $6(60 \%)$ & 0.3 \\
\hline LVEF (\%) & $27.6 \pm 1.9$ & $26.5 \pm 2.1$ & 0.7 \\
\hline NT-proBNP (pg/dl) & $1074 \pm 199$ & $850 \pm 497$ & 0.6 \\
\hline $\mathrm{IMT}(\mu \mathrm{m})$ & $650.3 \pm 23.0$ & $621.2 \pm 40.0$ & 0.5 \\
\hline FMD (\%) & $5.2 \pm 0.3$ & $6.2 \pm 1$ & 0.2 \\
\hline Peak $\mathrm{VO}_{2}(\mathrm{ml} / \mathrm{kg} / \mathrm{min})$ & $20.5 \pm 2.0$ & $23.7 \pm 2.4$ & 0.4 \\
\hline$\% \mathrm{VO}_{2}$ peak predicted & $81.9 \pm 4.6$ & $83.0 \pm 8.1$ & 0.9 \\
\hline $\mathrm{VE} / \mathrm{VCO}_{2}$ slope & $28.8 \pm 1.3$ & $25.5 \pm 2.0$ & 0.2 \\
\hline ACE-inhibitors & $23(92 \%)$ & $9(90 \%)$ & 0.9 \\
\hline Sartans & $2(8 \%)$ & $1(10 \%)$ & 0.7 \\
\hline Beta blockers & $22(88 \%)$ & $10(100 \%)$ & 0.5 \\
\hline Diuretics & $20(80 \%)$ & $8(80 \%)$ & 1.0 \\
\hline Spironolactone & $11(44 \%)$ & $3(30 \%)$ & 0.5 \\
\hline Statins & $19(76 \%)$ & $5(50 \%)$ & 0.3 \\
\hline
\end{tabular}

Means \pm Standard error of mean or absolute numbers (\%). BMI, Body Mass Index; LVEF, left ventricular ejection fraction; NT-proBNP, N-terminal pro-brain natriuretic peptide; NYHA, New York Heart Association class; Peak $\mathrm{VO}_{2}$, peak oxygen consumption; IMT, Intima Media Thickness; FMD, Flow Mediated Dilation 


\section{FIGURE LEGENDS}

Figure 1: Comparison of circulating EPC numbers (CD34+/KDR + cells, expressed as a percentage of lymphocytes) in chronic heart failure patients with Type D personality $(\mathrm{n}=10)$ versus non-Type $\mathrm{D}$ personality $(\mathrm{n}=25)$.

Figure 2: Effect size for advanced age ( $>65 \mathrm{yrs}$ ), unfavorable cardiovascular risk profile (Framingham Risk Score $\geq 6$ ) and Type D personality as determinants of the number of circulating EPC. An effect size of 0.50 reflects a moderate effect and 0.80 a large effect on the number of circulating EPC.

Figure 3: EPC numbers $(\mathrm{CD} 34+/ \mathrm{KDR}+$ cells, expressed as a percentage of lymphocytes) at baseline and after a single maximal exercise bout in chronic heart failure patients with Type D personality $(n=10)$ and non-Type D personality $(n=25)$ (Figure 3A). The change of EPC following exercise is significantly different in Type D patients compared to non-Type D patients. Figure 3B shows the significant increase in EPC migratory capacity following exercise in both Type D and non-Type D patients.

$P$-values are given for differences between Type $\mathrm{D}$ and non-Type $\mathrm{D}$ patients. ${ }^{*} P<$ 0.05 vs baseline. NS: non-significant vs baseline. 


\section{Figure 1}

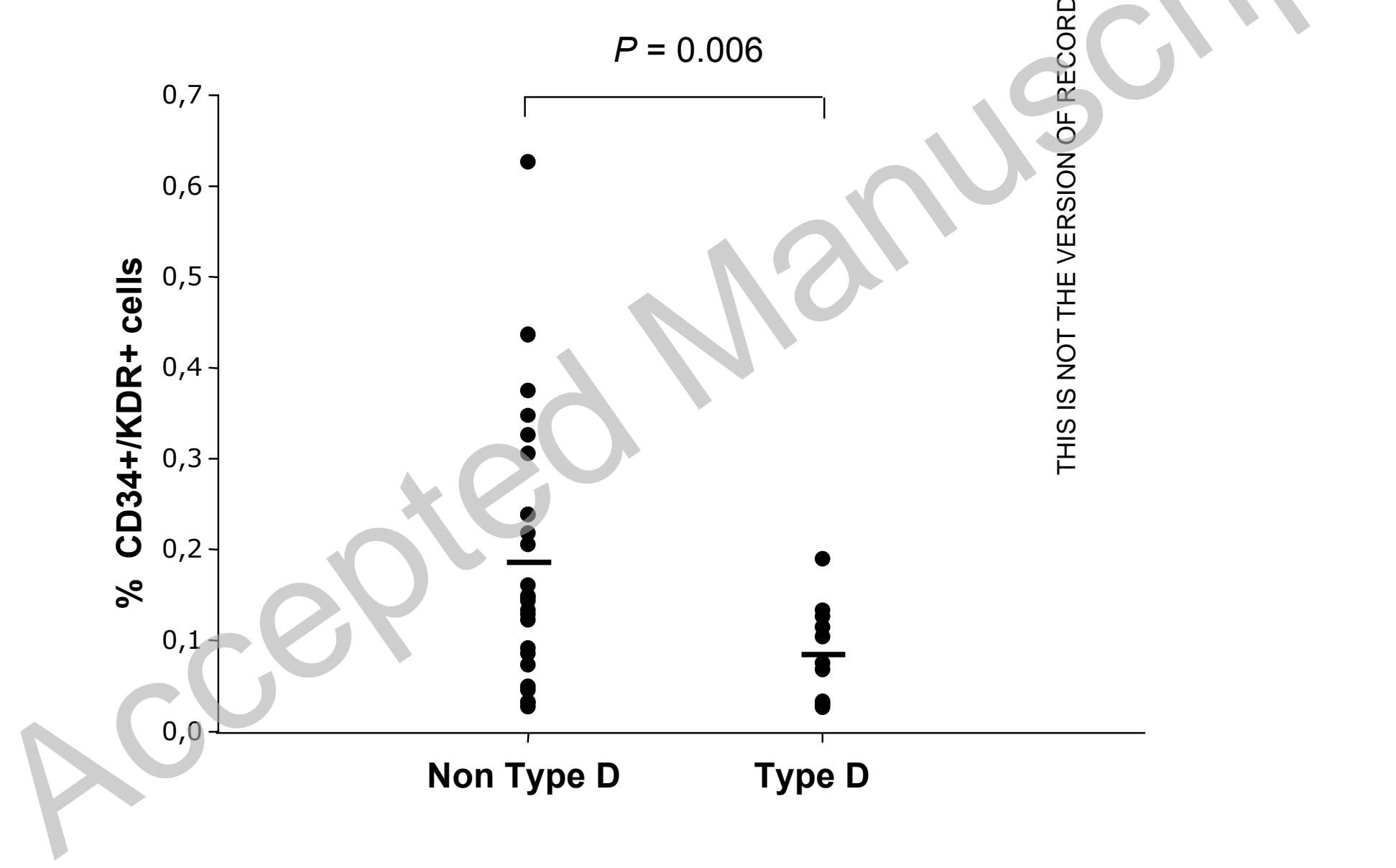


Figure 2

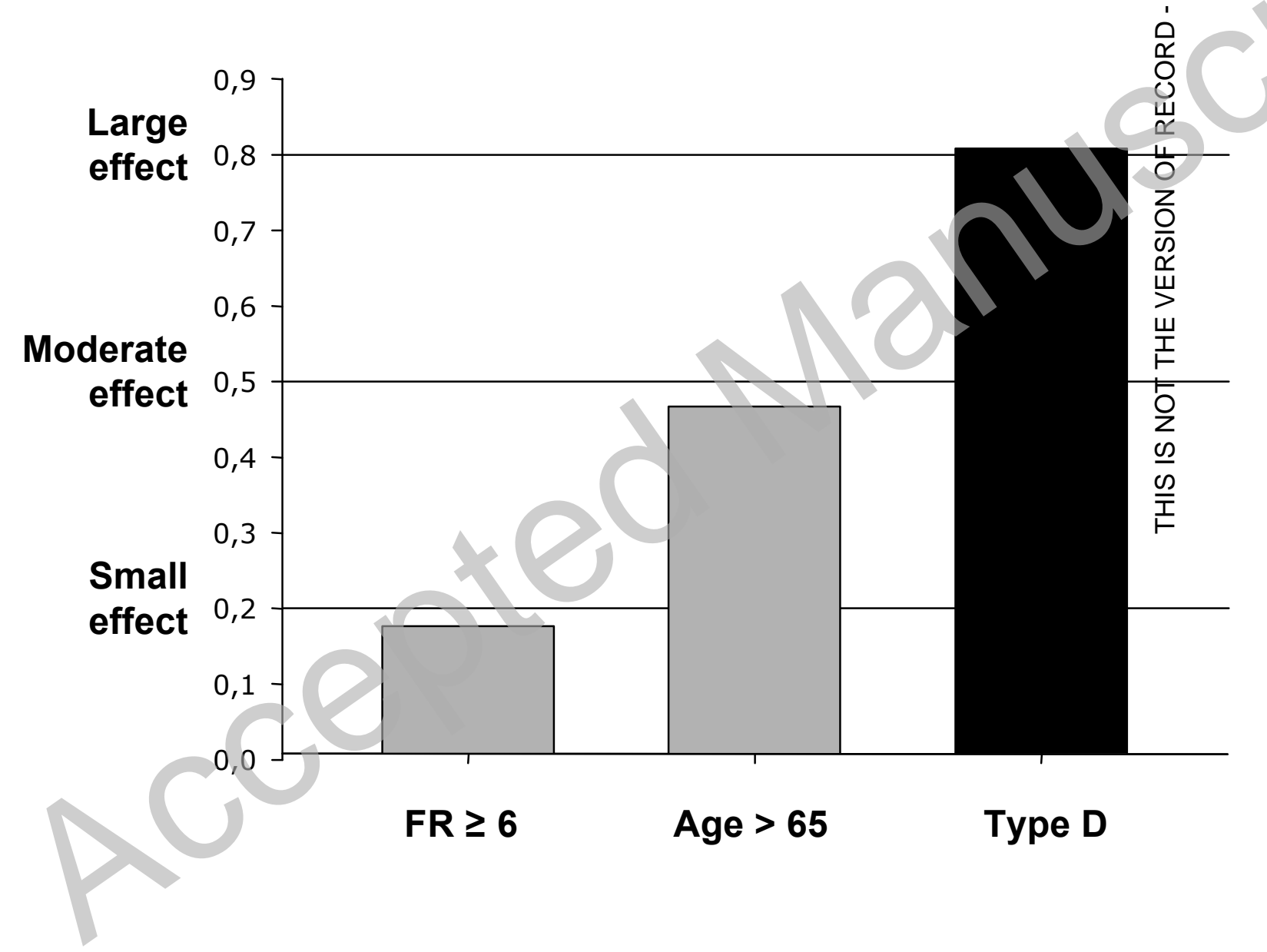


Figure 3

$3 A$
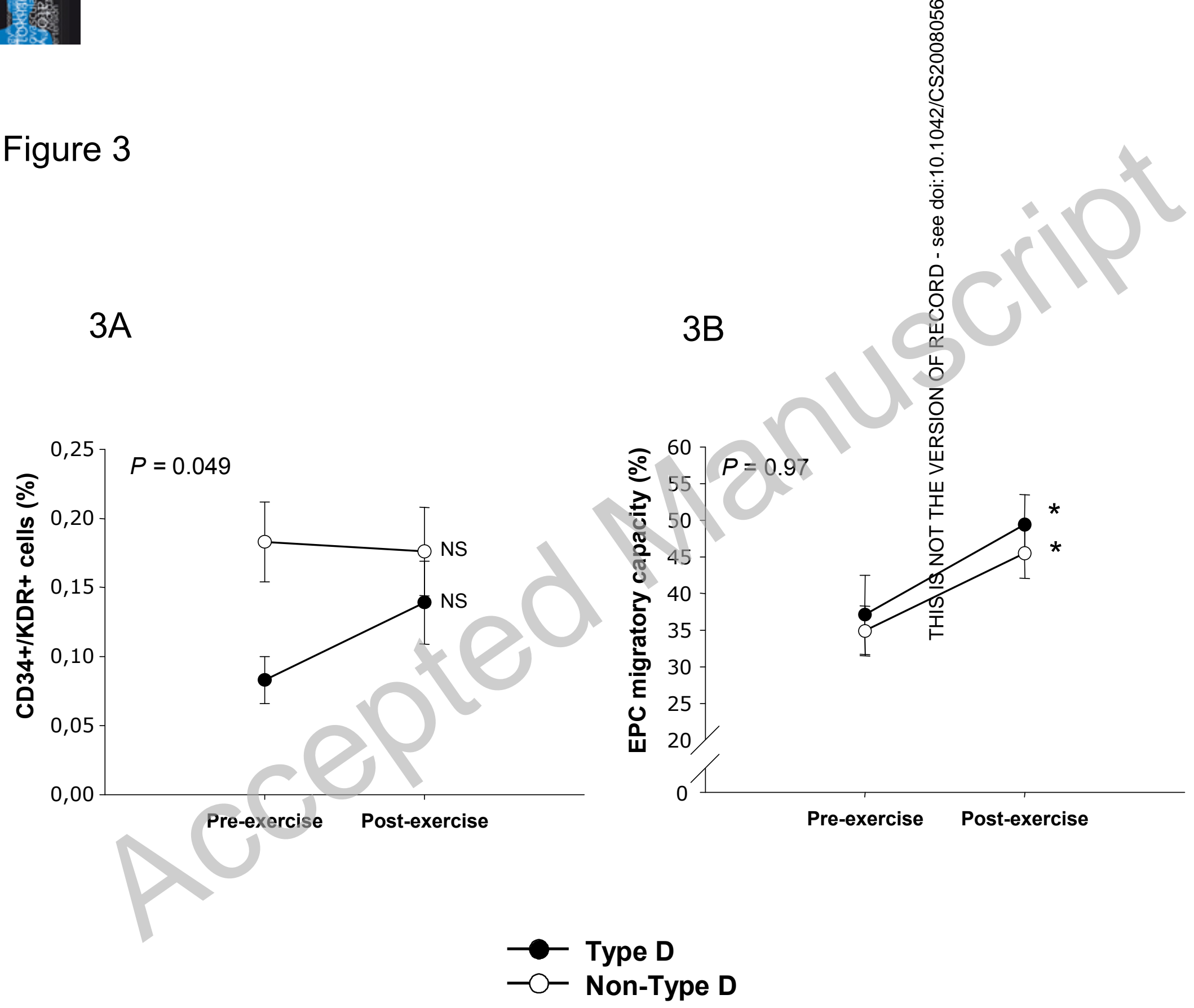

Licenced copy. Copying is not permitted, except with prior permission and as allowed by law. (C) 2009 The Authors Journal compilation @ 2009 Portland Press Limited 